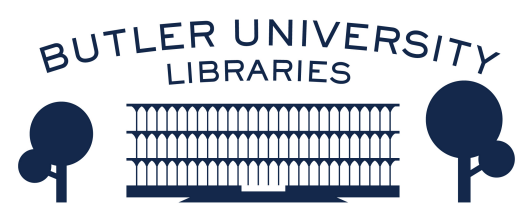

Journal of Hindu-Christian Studies

Volume 10

Article 17

January 1997

\title{
Book Review: "The Bible Trembled: The Hindu-Christian Controversies of Nineteenth Century Ceylon"
}

Joseph I. Richardson

Follow this and additional works at: https://digitalcommons.butler.edu/jhcs

Part of the Religion Commons

\section{Recommended Citation}

Richardson, Joseph I. (1997) "Book Review: "The Bible Trembled: The Hindu-Christian Controversies of Nineteenth Century Ceylon"," Journal of Hindu-Christian Studies: Vol. 10, Article 17.

Available at: https://doi.org/10.7825/2164-6279.1163

The Journal of Hindu-Christian Studies is a publication of the Society for Hindu-Christian Studies. The digital version is made available by Digital Commons @ Butler University. For questions about the Journal or the Society, please contact cbauman@butler.edu. For more information about Digital Commons @ Butler University, please contact digitalscholarship@butler.edu. 
the book and discuss it together, it should make a very important contribution to the conversation occurring between traditions today.
Francis X. Clooney, S.J.

Boston College

\section{The Bible Trembled: The Hindu-Christian Controversies of Nineteenth Century Ceylon. R. F. Young and S. Jebunesan. (Vol. XXII, Publications of the De Nobili Research Library). Vienna: Institute of Indology, University of Vienna, 1995.}

"THE BIBLE TREMBLED at the fierce battle engaged with Muttukamārak Kavirāyar (1780-1851); the Bible fell down and lay unconscious when attacked by Nāvalvar; and now it lies dead, smitten by Tāmōtaram Pillai (1832-1901)."

Capāpati Nāvalvar's poem reflects the intent and spirit of Hindu revivalism and anti-Christian sentiment in nineteenthcentury Jaffna, Ceylon (Śrī Lanka). His verse also provided an attractive title for this excellent book by $R$. F. Young and $S$. Jebunesan on Hindu-Christian controversies of the period. The authors have mapped the origins and development of Hindu revival movements with great skill considering the diversity of elements involved in such a study. The approach is basically historical but the events are presented in the context of socio-religious movements in which the Hindu communities are seen to be concerned with the revitalization of their society "by reference to a past, remembered nostalgically, when religion was thought to be pure and society conducted itself accordingly". The bibliography for this study is encyclopedic. It is used in such a way as to let the protagonists in the controversies speak for themselves in language which ranges from egregious calumny to sublime philosophical discourse.

The engagement of Christians and Hindus was not a simple matter of contention between entrenched, well-defined orthodoxies, nor was it a case of repetitive argument about points of theological or doctrinal difference and disagreement. Issues changed over the period. Hindu astrology contended with true astronomy; historical Bible contended with mythic Purana; the moral character of deities was debated; the use of idols was condemned and defended. In addition, Tamil Śaivites were having their own struggles within the larger Hindu community. The concern of non-brahmin castes about the Dravidian rather than the Sanskrit origins of their culture, language, and religion resulted in growing animosity toward the Sanskritized Brahmins, their ritual patterns and scriptural bases. Christian missionaries felt they had an ally with this kind of reform but learned to their chagrin that it was a powerful force in the strengthening of Hindu self-esteem.

In their mapping the authors delineate the differences that characterized religious reforms in various areas. Those on which they concentrate were in the north of Śrī Lanka around Jaffna in the Saivite Hindu communities. There were movements in the south among the Buddhist Sinhalese but they were quite different in origin and manifestation. Similarly the Tamils of mainland India were engaged in reform movements which have similarities but significant differences. Elaborating the details of these variations has given a sense of time and location as well as introduced us to the personalities involved.

The coming of protestant Christianity to Jaffna had profound results. These results were not those anticipated by the 
missionaries who hoped for the conversion and "enlightenment" of native peoples. Many Hindus were attracted to the new Western education as well as to the religion and ethics of Christianity. Some were converted and baptized; many seemed to be converted and later changed their minds and became fierce adversaries of Christianity. In the process, Śaiva Hinduism was revitalized and changed. Old elements were brought forward and reformulated, new elements were adapted from their protagonists.

Hindu apologists became adept in a form of Biblical criticism which seems to have been a blend of Christian Apologetics and traditional Hindu religious debate. To illustrate the nature and development of this apologia the authors have chosen major figures and examined their history and methodology in great detail. According to Capapapti, the Saivite revivalist who is quoted at the beginning of this review, there were three giants who slew the Bible. Muttukkumārak Kavirāyar first made the Bible "tremble", Ārumuka Nāvalar then "knocked it unconscious", and the coup de grace was delivered by a third critic, $\mathbf{C}$. W. Tāmōtaram Pillai who struck it so hard that it now "lies dead". Two other apologists carried the arguments further, Cankara Pantitar (1829-1870) and Ponnambalam
Ramanathan (1851-1930). Of these Cankara in particular used concepts from the sophisticated Śaiva Siddhānta in his critique of the Bible and Christianity. The detailed portrayal of these apologists illuminates both the intent and methodologies of the nineteenth-century Śaivite renewal in Śrī Lanka.

This book is an important contribution to the continuing study of regional Hindu revitalization movements. The bibliography covers a vast range of historical and literary material which provides a rich resource for further studies of the period.

It is not an easy book to read, though well worth the effort. The volume and variety of material encompassed is daunting. It does "map" the period, but it would be helpful to the reader to have an "insert" here and there to illuminate where we have been and how we got there! Students of the "Hindu Renaissance" who are unfamiliar with Tamil may find some difficulty with Tamil language, place names, family and caste designations, and methods of transliteration - inevitable challenges in regional studies.

Joseph I. Richardson Victoria

\section{Dilemmas of Life and Death: Hindu Ethics in North American}

Context. S. Cromwell Crawford. Albany, NY: State University of New York Press, 1995, ix +233 pp.

and

\section{Divine Nature: A Spiritual Perspective on the Environmental}

Crisis. Michael A. Cremo and Mukunda Goswami. Los Angeles: Bhaktivedanta Book Trust, 1995, xx+108 pp.

THE STUDY OF ethics in the Western world from the time of the Greeks right up to two decades ago has been focused on issues that were almost entirely humancentred or God-centred. Thus, for most of its intellectual history the Western world, with its Greek and Christian leadership, has paid little attention to the ethical responsibilities humans may have in the interaction with plants, animals, earth, air, and water - 